\title{
PROFESIONALISME SEORANG PENDIDIK
}

\author{
Galuh Nur Syifa \\ Email: 2010111320002@mhs.ulm.ac.id \\ Program Studi Pendidikan Sejarah Fakultas Keguruan dan Ilmu Pendidikan \\ Universitas Lambung Mangkurat \\ Banjarmasin
}

\begin{abstract}
Abstrak
Profesionalisme merupakan tuntutan bagi seseorang yang memiliki pekerjaan sebagai profesi. Tuntutan tersebut berupa keahlian, keterampilan, pengetahuan, dan kecakapan dalam menjalani bidang profesinya. Profesi guru merupakan salah satu pekerjaan profesi di Indonesia. Guru yang profesional memiliki peran yang sangat penting, yaitu sebagai contoh bagi peserta didik, memberikan motivasi, sebagai fasilitator dan yang tercantum dalam Undang-undang No. 14 Tahun 2005 mengenai Guru dan Dosen yang mana seorang guru harus memiliki empat kompetensi dasar agar menjadi guru yang profesional. Kompetensi dasar tersebut yaitu: kompetensi profesional, kompetensi pedagogik, kompetensi sosial, dan kompetensi kepribadian. Dari keempat kompetensi tersebut guru dapat melaksankan kewajibannya sebagai seorang pendidik. Dengan demikian, jika kewajibannya telah terlaksana maka guru akan mendapatkan hak yang semestinya didapat. Kewajiban guru adalah untuk meciptakan generasi mendatang menjadi suatu generasi yang dapat memajukan dan mencerdaskan bangsa Indonesia.
\end{abstract}

\section{PENDAHULUAN}

Profesi secara etimologi berasal dari kata profession artinya pekerjaan. Sedangkan professional adalah tenaga ahli atau orang yang memiliki keahlian. Professionalism berarti sifat dari professional. (John M. Enchols \& Hassan Shadily, 1990: 449). Konsep profesi berarti merupakan suatu pekerjaan yang menuntut keahlian dan setiap orang yang memiliki pekerjaan sebagai profesi harus mengembangkan kapasitas pengetahuannya.

Dalam Kamus Besar Bahasa Indonesia ungkapan profesi berarti suatu pendidikan keahlian berupa keterampilan, kejuruan, dan sebagainya guna melandasi sebuah bidang dalam pekerjaan. Kepandaian yang khusus sangat diperlukan untuk seseorang yang profesional.

Bidang keilmuan profesi fokus utamanya adalah pengabdian dan tanggung jawab moril. Secara umum suatu pekerjaan memiliki beberapa syarat agar dapat digolongkan sebagai sebuah profesi, yaitu: memiliki spesialisasi dalam bidang ilmu pengetahuan, untuk 
menjalankan profesinya memiliki kode etik, di dalam sebuah profesi terdapat organisasi profesi yaitu perkumpulan orang-orang yang memiliki profesi yang sama, profesi tersebut diakui oleh masyarakat contohnya dokter, guru, pilot, lalu pekerjaan tersebut merupakan panggilan hidup karena pekerjaan profesi merupakan pengabdian diri secara penuh terhadap profesi tersebut, syarat selanjutnya memiliki kecakapan diagnostik, dan syarat terakhir adalah memiliki klien yang jelas, misalnya dokter kliennya adalah pasien, guru kliennya adalah peserta didik, dan sebagainya.

Banyak berbagai macam profesi pekerjaan di Indonesia, salah satunya adalah profesi guru. Profesi guru berarti seorang guru tersebut memiliki keahlian mengajar dalam ilmu pengetahuan dan ahli dalam mendidik peserta didik. Profesi guru di Indonesia dilandasi oleh hukum Undang-undang No. 14 Tahun 2005 tentang Guru dan Dosen.

\section{PERAN GURU SEBAGAI SEBUAH PROFESI}

Guru digolongkan sebagai sebuah profesi karena untuk mendapatkan jabatan sebagai seorang guru tidak sembarang orang mendapatkannya. Guru tidak hanya mengajar, memberikan ceramah, dan tugas kepada peserta didik. Tugas guru lebih dari itu. Maka dari itu, dibutuhkan seseorang yang memiliki keahlian dalam mengajar, mendidik, menjadi fasilitator bagi peserta didiknya. Tercantum di dalam landasan hukum profesi guru Indonesia bahwa seorang guru harus memiliki empat kompetensi pokok agar menjadi guru yang profesional.

Yang mana agar terwujudnya itu semua perlu persiapan melalui pendidikan dan pelatihan dan tidak dapat dilakukan oleh sembarangan orang. Sebagai profesi guru titik utamanya adalah pengabdian dan tanggung jawab sesuai dengan bidang guru tersebut, tidak semua orang mampu menjadi guru. Sebab yang mampu menjadi guru merupakan panggilan hidup.

Contoh seorang ibu yang mengajarkan anaknya pada saat pembelajaran jarak jauh. Namun, ibu tersebut tidak mengerti atau memahami keinginan anaknya. Sementara seorang guru saat dalam pelatihan persiapan menjadi seorang guru, ia belajar tentang kepribadian peserta didik atau perkembangan dari peserta didik. Jadi, guru tahu apa yang harus dilakukannya untuk memahami atau menghadapi peserta didiknya. Inilah yang menjadika guru digolongkan sebagai profesi, sebab tidak sembarang orang dapat mengerti keinginan dari peserta didik, kecuali jika ia belajar atau melakukan pelatihan untuk menjadi guru.

Di dalam Undang-undang No.14 Tahun 2005 tentang Guru dan Dosen mengatakan bahwa guru memiliki peran, hak, dan kewajibannya dalam menjalankan profesi tersebut. Peran guru sangat kompleks dalam perkembangan peserta didiknya. Dikarenakan guru bertugas untuk mendidik, meneruskan, dan mengembangkan nilai-nilai kehidupan kepada peserta didiknya agar keterampilan tersebut dapat diterapkan di kehidupan selanjutnya peserta didiknya. (Djamarah, 2000:37). 
Indonesia memiliki filosofi pendidikan yang dicetuskan oleh Bapak Pendidikan Nasional yaitu Ki Hadjar Dewantara "ing ngarso sung tulodo, ing madya mangun karso, tutwuri handayani." Dari filosofi tersebut terbentuknya peran guru yaitu pertama guru sebagai contoh dan pedoman bagi peserta didiknya dalam kegiatan pembelajaran maupun diluar kegiatan pembelajaran, lalu peran guru kedua adalah guru sebagai inovasi bagi peserta didik untuk menggerakan peserta didik ke jalan yang benar, dan peran ketiga ialah guru harus memberikan semangat berupa motivasi dan dorongan kepada peserta didik agak terbakar semangat juang dalam menjalani kehidupannya.

Maka tugas guru tidak hanya sebatas lingkungan sekolah saja, tetapi juga sebagai penghubung antara peserta didik dengan kondisi masyarakat dan lingkungannya (Djamarah, 2000:37). Dimana kemampuan guru harus menguasai atau mengikuti perkembangan dari ilmu pengetahuan teknologi.

Hak guru dalam Undang-undang No.14 Tahun 2005 tentang Guru dan Dosen merupakan setelah guru melakukan sebuah kewajibannya sebagai pendidik berarti ia mendapatkan sesuatu yang semesti atau hak guru. Hak guru tersebut dapat berupa gaji atau penghasilan guna kebutuhan hidupnya setelah ia mengajar dan mendapatkan jaminan untuk kesejahteraan sosialnya, dengan peran dan kewajiban yang telah dilaksanakan apabila guru tersebut memiliki prestasi maka ia akan mendapatkan penghargaan berupa promosi, dalam kewajiban tersebut guru mendapatkan perlindungan dalam menjalankan tugasnya, kebebasan untuk berserikat dengan organisasi profesi, dan memperoleh rasa keamanan dalam menjalankan tugasnya sebagai guru. Dan masih banyak lagi hak yang akan diterima seorang guru, jika ia juga melaksanakan kewajibannya. Sebaiknya dengan hak-hak yang didapatkan oleh seorang guru dapat membuat ia melaksanakan kewajibannya secara maksimal untuk memajukan pendidikan bangsa Indonesia.

\section{GURU INDONESIA DAN TANTANGAN PROFESIONALISME}

Profesionalisme seperti pengertian diatas merupakan sifat profesional. Dimana setiap pekerjaan yang berprofesi dituntut keahliannya dalam bidang tertentu dan kepandaiannya dalam menjalankan profesi tersebut agar menjadi seorang yang profesional. Sama halnya dengan profesionalisme guru, itu sangat diperlukan guna memajukan pendidikan Indonesia. Mengapa? Dikarenakan untuk memajukan bangsa Indonesia dalam bidang pendidikan diperlukan guru yang paham dan mengerti keadaan pendidikan sekarang. Guru dapat disebut sebagai guru yang profesional apabila telah memenuhi empat kompetensi pokok yang harus dimiliki terdapat dalam Undang-undang No. 14 tahun 2005. Dimana komponen kompetensi tersebut yaitu: kompetensi profesional, kompetensi pedagogik, kompetensi sosisal, dan kompetensi kepribadian. 
Jika profesi sebagai guru hanya memiliki satu kompetensi itu tidak akan disebut guru profesional. Misalnya, jika guru hanya memiliki kompetensi profesional dimana hanya mengetahui dasar ilmu pengetahuan tanpa adanya kompetensi pedagogik yang dapat memahami peserta didik, ditambah lagi tidak memiliki kompetensi sosial yang sangat berpengaruh dalam proses pembelajaran dan tidak memiliki daya tarik untuk menarik perhatian peserta didik di bidang kompetensi kepribadian, maka ia tidak akan dapat menjalankan profesinya sebagai seorang guru. Karena dari keempat kompetensi pokok guru ini sangat berhubungan dan saling berkaitan.

\section{SIMPULAN}

Profesi merupakan suatu pekerjaan yang menuntut keahlian dan harus mengembangkan kapasitas pengetahuan terhadap bidang profesinya untuk menjadi seorang yang profesional. Bidang keilmuan profesi fokus utamanya adalah pengabdian dan tanggung jawab moril.

Banyak berbagia macam profesi pekerjaan di Indonesia, salah satunya adalah profesi guru. Guru digolongkan sebagai sebuah profesi karena tidak sembarang orang mendapatkan jabatan sebagai seorang guru. Tugas guru tidak hanya mengajar, memberikan ceramah, dan tugas kepada peserta didiknya. Tugas guru lebih dari itu, maka dibutuhkan seseorang yang memiliki keahlian dalam mengajar, mendidik, dan menjadi fasilitator bagi peserta didik.

Untuk dapat memenuhi itu semua, guru diharuskan memiliki kompetensi pokok. Kompetensi pokok dibentuk pada saat persiapan sebelum terjun langsung ke dalam dunia pendidikan. Misalnya pada saat belajar dibangku perkuliahan, mengikuti pelatihan-pelatihan, dan sebagainya. Dengan demikian, jika terwujudnya kompetensi pokok guru akan tercipta pula para guru yang profesional dalam bidangnya.

\section{REFERENSI}

Djamarah, S.B. (2000). Guru dan Anak Didik Dalam Interaksi Edukatif. Jakarta: PT Rineka Cipta.

Efendi, I., Prawitasari, M., \& Susanto, H. (2021). Implementasi Penilaian Pembelajaran Pada Kurikulum 2013 Mata Pelajaran Sejarah. Prabayaksa: Journal of History Education, 1(1), 21-25.

John M. Enchols \& Hassan Shadily. (1990). Kamus Inggris Indonesia. Jakarta: Gramedia.

Sekretariat Negara, UURI No. 14 Tahun 2005 Tentang Guru dan Dosen.

Susanto, H. (2020). Profesi Keguruan. Banjarmasin: FKIP Universitas Lambung Mangkurat. 
Susanto, H., \& Akmal, H. (2018). Efektivitas Penggunaan Aplikasi Pembelajaran Berbasis Mobile Smartphone Sebagai Media Pengenalan Sejarah Lokal Masa Revolusi Fisik Di Kalimantan Selatan Pada Siswa Sekolah Menengah Atas. HISTORIA: Jurnal Program Studi Pendidikan Sejarah, 6(2), 197-206.

Susanto, H., Irmawati, I., Akmal, H., \& Abbas, E. W. (2021). Media Film Dokumenter Masuknya Islam Ke Nusantara dan Pengaruhnya Terhadap Keterampilan Berpikir Kritis Siswa. HISTORIA: Jurnal Program Studi Pendidikan Sejarah, 9(1).

Syaharuddin, S., \& Susanto, H. (2019). Sejarah Pendidikan Indonesia (Era Pra Kolonialisme Nusantara sampai Reformasi). Banjarmasin: FKIP Universitas Lambung Mangkurat. 